\title{
Fbxw7 haploinsufficiency loses its protection against DNA damage and accelerates MNU-induced gastric carcinogenesis
}

\author{
Yannan Jiang ${ }^{1}$, Xinming $\mathbf{Q i}^{2}$, Xinyu Liu ${ }^{1}$, Jun Zhang ${ }^{1}$, Jun Ji $^{1}$, Zhenggang Zhu ${ }^{1}$, Jin \\ Ren ${ }^{2}$, Yingyan $\mathbf{Y u}^{1}$ \\ ${ }^{1}$ Department of Surgery of Shanghai Ruijin Hospital, Shanghai Institute of Digestive Surgery, Shanghai Key Laboratory for \\ Gastric Neoplasms, Shanghai Jiao Tong University School of Medicine, Shanghai, 200025, China \\ ${ }^{2}$ Center for Drug Safety Evaluation and Research, Shanghai Institute of Materia Medica, Chinese Academy of Sciences, \\ Shanghai, 201203, China
}

Correspondence to: Yingyan Yu, email: yingyan3y@sjtu.edu.cn

Keywords: Fbxw7, knockout mouse, N-Methyl-N-nitrosourea, gastric cancer, DNA damage

Received: January 17, 2017 Accepted: March 22, 2017 Published: April 03, 2017

Copyright: Jiang et al. This is an open-access article distributed under the terms of the Creative Commons Attribution License (CC-BY), which permits unrestricted use, distribution, and reproduction in any medium, provided the original author and source are credited.

\section{ABSTRACT}

Fbxw7, a subunit of the SCF E3 ubiquitin ligase, recognizes oncoprotein substrates and leads to their proteasomal degradation. Fbxw7 acts as a tumor suppressor via inducing apoptosis and growth arrest in various kinds of tumors. To clarify the initiating role in gastric carcinogenesis as well as the histologic characterization of tumor in Fbxw7 allele haploinsufficient mice, we generated Fbxw7 heterozygous knockout mice (Fbxw $7^{+/-}$) and treated them with chemical carcinogen $\mathrm{N}$-methyl-N-nitrosourea (MNU) at 5-6 weeks of age. We also treated mouse embryo fibroblasts (MEFs) from Fbxw7 $7^{+/-}$and Fbxw7 $7^{+/+}$mice with MNU and examined cell DNA damage via comet assay. The protein expression of Fbxw7 and its substrate c-Myc from mouse tumors, as well as human tumors sampled from six patients, were detected by Western blot. As results, the tumor incidence was obviously higher in Fbxw $7^{+/-}$mice $(13 / 20)$ than in Fbxw7 $7^{+/+}$mice $(6 / 20)$ after 35 -week observation. Intestinal metaplasia $(P=0.013)$ and dysplasia $(P=0.036)$ were more severe in Fbxw7 $7^{+/-}$mice than in Fbxw7 $7^{+/+}$mice. The repair potential of DNA damage was suppressed in MEFs from Fbxw $7^{+/-}$mice after MNU exposure. Increased c-Myc expression was accompanied by decreased Fbxw7 protein expression in tumor tissues from mouse and patients. In conclusion, Fbxw7 haploinsufficiency increased the risk of gastric carcinogenesis induced by MNU, which is associated with the accumulation of DNA damage as well as c-Myc oncoprotein.

\section{INTRODUCTION}

Gastric cancer is one of the most common cancers worldwide [1]. It is thought to result from a combined attack by environmental factors and genetic alterations [2]. Activation of oncogenes and silence of tumor suppressors play important roles in gastric carcinogenesis. Fbxw7, a member of the F-box family which is a component of the SKIP-CUL1-F-box protein (SCF) E3 ubiquitin ligase complex, mediates the recognition and binding of its substrate proteins, leading to their K48 ubiquitination and proteasomal degradation [3]. The substrates of Fbxw7 include c-Myc, CyclinE, c-Jun, mTOR, KLF5, Notch1 and Notch4 $[4,5]$. Most of them have been shown as oncogenes in multiple types of human cancers. Recent studies revealed that Fbxw7 regulates apoptosis, growth arrest, and epithelial-to-mesenchymal transition in gastric cancer [6]. A reduced expression of Fbxw7 is detected in gastric tumors compared to the paired non-neoplastic specimens and is associated with a highly invasive phenotype in gastric cancer cell lines $[7,8]$. In general, Fbxw7 displays a mutation frequency about $6 \%$ in multiple human cancers, including gastric cancer [9-11]. Genetic inactivation of Fbxw7 causes chromosomal instability characterized by aneuploidy and micronucleus formation [12] and is associated with the increased rate of radiationinduced tumors [13]. FBXW7 promotes ubiquitination of XRCC4 via lysine 63 linkage to facilitate nonhomologous end-joining, rather than proceeds to XRCC4 degradation [14], while these two pathways of ubiquitination (via K48 
and K63 linkage) contribute to the tumor suppressor role of FBXW7 together.

Haploinsufficiency refers to a phenotype in which a diploid cell lost one allele of a gene, and the remaining copy of the gene cannot provide sufficient gene function to maintain the cell phenotype. Haploinsufficiency means a situation for tumor suppression in which functional loss of one allele results in a selective acceleration for tumor growth [15]. Loss of function of tumor suppressors Pten, Dicer1, and Cdkn1b was associated with haploinsufficiency in animal experiments [16-19]. One copy deletion of Fbxw7 gene with a frequency of $45.5 \%$ was observed in gastric tumors [8]. Both Tetzlaff, et al. and Tsunematsu, et al. found that homozygous loss of Fbxw7 led to embryonic death in mice due to the abnormality of heart and vessels, while heterozygous mutation appeared normal and did not develop spontaneous tumors up to 12 months [20, 21]. Mao, et al. crossed Fbxw7 heterozygous knockout mice with p53 knockout mice and found that loss of one allele of Fbxw7 increased the lymphoma formation in p53 knockout mice [13]. Fbxw $7^{+/-}$ heterozygous mutation also increased tumors in $\mathrm{APC}^{\mathrm{min} /+}$ mice and decreased the survival rate [22]. Thus, Fbxw7 haploinsufficiency is related to the increased tumor incidence in animal experiments.

N-methyl-N-nitrosourea (MNU), a chemical carcinogen, has been widely used in gastric carcinogenesis study on mouse models $[23,24]$. In our study, we treated Fbxw7 systematically knockout mice with MNU, and investigated the impact of Fbxw7 haploinsufficiency on gastric carcinogenesis. We also analyzed the possible attacking mechanisms of Fbxw7 dysfunction on murine somatic cells.

\section{RESULTS}

\section{Construction of Fbxw7 knockout mice}

The Fbxw $7^{\text {Bgeo }}$ ES cell (a flexible gene-trap knockout-first, lacZ tagged insertion Fbxw7 allele) was obtained from EUCOMM for generating Fbxw $7^{\text {Bgeo }}$ mice. These ES clones had passed all rigorous quality control tests of the EUCOMM. Due to homologous recombination, the wild-type allele was replaced by Fbxw $7^{\text {Bgeo }}$ allele whose gene function would be ablated by a polyadenylation (polyA) signal-mediated transcriptional stop at the end of the lac $\mathrm{Z}$ expression marker gene. Fbxw $7^{\text {Bgeo/+ }}$ mice maintained on C57BL/6 genetic background (Figure 1A). Genotyping analysis of the newborn offsprings indicated that $\mathrm{Fbxw} 7^{\mathrm{Bgeo} /+}$ and Fbxw $7^{+/+}$mice were alive, while Fbxw $7^{\text {Bgeo/ } / \text { geo }}$ mice died in embryonic stage, which is consistent with previous reports $[20,21]$. The product of PCR with two bands at 232bp and $359 \mathrm{bp}$ represents the heterozygous genotype, and product with one band at $359 \mathrm{bp}$ represents the wild-type one (Figure 1B). Fbxw $7^{\text {Bgeo/+ }}$ were systemically heterozygous knockout mice $\left(\mathrm{Fbxw} 7^{+/-}\right)$. Fbxw $7^{+/+}$were wild-type mice. 40 mice were used in gastric carcinogenesis study $\left(20 \mathrm{Fbxw} 7^{+/-}\right.$mice and $20 \mathrm{Fbxw} 7^{+/+}$mice, Figure $\left.1 \mathrm{C}\right)$.

\section{Increased gastric cancer susceptibility of Fbxw $7^{+/-}$mice under MNU treatment}

The mice of experimental group $\left(\mathrm{Fbxw} 7^{+/-}\right)$and control group $\left(\mathrm{Fbxw}^{+/+}\right)$were treated with $\mathrm{MNU}$ in drinking water for 5 weeks, and sacrificed at 35 weeks. No death or weakness was observed. We found no abnormality of mice in chest and abdominal cavity autopsy. Then we cut the stomach along the greater curvature and recorded the tumors. The incidence of gastric tumors in $\mathrm{Fbxw}^{+/-}$ mice was much higher than in wild-type mice (13/20 vs $6 / 20, P=0.056$, Figure 2A). Slides of stomach tissues were stained by hematoxylin-eosin reagent and scored for pathology on a scale of 0 to 4 , as previously described [25]. The standard for pathology score was listed on Table 1. The results showed more severe intestinal metaplasia and dysplasia in $\mathrm{Fbxw}^{+/-}$mice than in wild-type mice ( $P=0.013$ and $P=0.036$, separately, Figure 2Aii). We tested the mRNA expression of Fbxw7 in tumors. All of the tumors from $\mathrm{Fbxw}^{+/-}$mice expressed $\mathrm{Fbxw} 7$, though the expression levels were lower than controls $(P=0.0135)$ (Figure 2B). The results suggested that the lower expression of Fbxw7 and the higher incidence of gastric cancer were attributed to the Fbxw7 haploinsufficiency. We noticed that most gastric tumors were located in the antrum (antrum vs corpus equals to $16 / 19$ vs $2 / 19$, remaining $1 / 19$ was mixed location, Figure $2 \mathrm{C}$ ). All of the gastric tumors induced by MNU were intestinal-type carcinoma.

\section{Decreased apoptosis of gastric mucosa in Fbxw7 $7^{+/-}$mice}

We compared the apoptosis of gastric mucosa by TUNEL assays, and found the apoptotic bodies per field in $\mathrm{Fbxw}^{+/-}$mice were much less than in Fbxw $7^{+/+}$mice $(P=0.042)$. Apoptotic bodies of wild-type mice could be found in the mucosal glands as well as in the exfoliated epithelial cell masses (Figure 3B, 3C). The growth activity of gastric mucosa was assayed by Ki67 labeling. There was no significant difference in percent of Ki67 positive cells between $\mathrm{Fbxw} 7^{+/-}$mice and controls. Ki67 positive cells were mainly observed in the bottom of crypts of noncancerous regions, while increased Ki67 positive cells were observed in dysplastic or cancerous regions (Figure 3A, 3C).

\section{Delayed DNA damage repair in MEFs from Fbxw $7^{+/-}$mice}

To investigate the repair ability of DNA damage after MNU exposure, we assayed $\mathrm{pH} 2 \mathrm{AX}$ expression on MEFs from $\mathrm{Fbxw}^{+/-}$and $\mathrm{Fbxw}^{+/+}$mice by immunofluorescence. The percent of $\mathrm{pH} 2 \mathrm{AX}$ positive cells 
and relative density of fluorescence reached a peak at $2 \mathrm{~h}$ post MNU exposure and then decreased gradually in both genotypes. However, the percent of $\mathrm{pH} 2 \mathrm{AX}$ positive cells $(P<0.05$ at $4 \mathrm{~h}, 8 \mathrm{~h}, 12 \mathrm{~h}$ and $18 \mathrm{~h})$ and relative density $(P<0.05$ at $4 \mathrm{~h}, 8 \mathrm{~h}$ and $12 \mathrm{~h})$ of fluorescence declined more slowly in $\mathrm{Fbxw} 7^{+/-} \mathrm{MEF}$ s than in wild-type MEFs (Figure 4). We also conducted the comet assay to examine the DNA damage repair in these two MEFs. The results revealed that DNA strand breaks were repaired at $12 \mathrm{~h}$ in wild-type MEFs, while the repair was not complete until $18 \mathrm{~h}$ in Fbxw $7^{+/-}$MEFs. Both tailDNA\% and tail length were significantly different at $2 \mathrm{~h}$ to $12 \mathrm{~h}(P<0.05)$ (Figure 5). Western blotting of $\mathrm{pH} 2 \mathrm{AX}$ showed similar trends (Figure 6A). The microscopic view and results of genotyping examination of MEFs were presented in Figure 6A.

\section{Upregulated c-MYC expression in gastric tumors}

Since c-MYC protein is degraded via FBXW7mediated ubiquitin pathway, we examined the protein expression of FBXW7 and c-MYC in gastric tumors and paired normal tissues from six patients (Figure 6C) and mouse models (Figure 6B). We found that the protein expression pattern of FBXW7 and c-MYC were reversely correlated. The decreased FBXW7 expression was accompanied by increased c-MYC expression in cancerous tissues, compared to corresponding normal tissues.

\section{DISCUSSION}

Fbxw7 gene alteration has been found in a variety of tumors, such as lymphoma, glioma, colorectal cancer and gastric cancer $[12,13,26,27]$. Recently, several genomic sequencing on gastric cancer revealed that the mutant frequency of Fbxw7 gene was about 6-9\%, which further suggested the possible role of Fbxw7 gene on gastric carcinogenesis $[9,10,28-30]$. In order to clarify the function of Fbxw7 gene, we constructed Fbxw7 knockout mice. According to literatures, homozygous loss of Fbxw7 is an embryonic dead event, while heterozygous mice show normal phenotype without spontaneous tumors. But the accelerated tumorigenesis had been noticed in lymphoma and colon cancer in Fbxw7 heterozygous
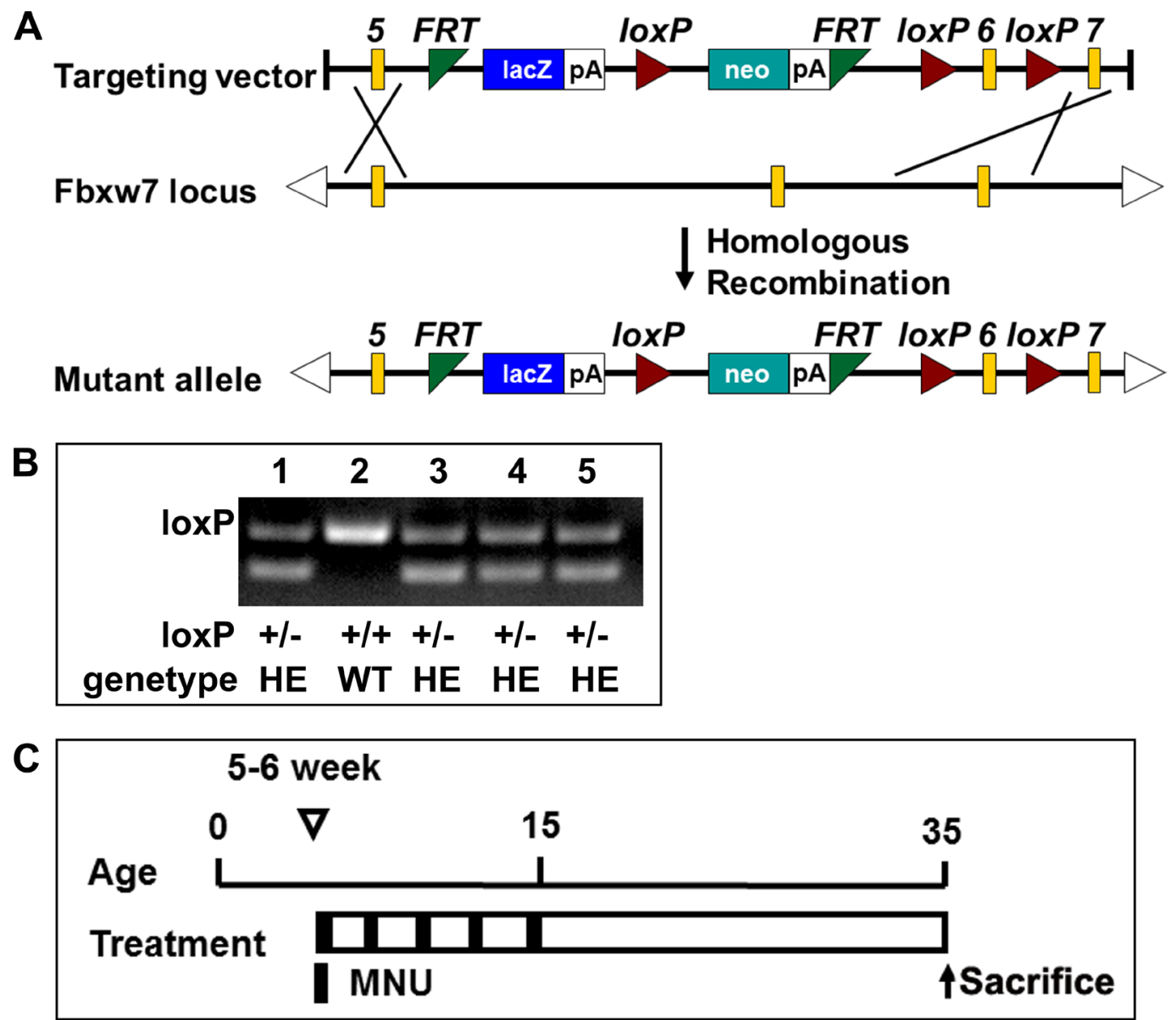

Figure 1: Fbxw7 knockout mice construction and treatment with MNU. (A) Schematic diagram of the creating Fbxw7 heterozygous knockout mice. (B) Genotyping using mouse tail DNA at the age of 2 weeks. PCR screening for the mutant allele revealed a band of 232bp for the wild type allele and 359bp for the mutant allele. (C) Experimental design of MNU treatment. The 5-6 weeks old mice were given MNU $240 \mathrm{mg} / \mathrm{L}$ in drinking water, every other week for a total exposure of 5 weeks. 
Table 1: Murine gastric histopathology scoring paradigm

\begin{tabular}{|c|c|c|c|c|c|}
\hline \multirow[t]{2}{*}{ Parameters } & \multicolumn{5}{|c|}{ Score } \\
\hline & $\mathbf{0}$ & 1 & 2 & 3 & 4 \\
\hline Inflammation & no inflammatory cells & $\begin{array}{l}\text { inflammatory cells } \\
\text { infiltration of the } \\
\text { submucosa with or } \\
\text { without infiltration } \\
\text { at the very base of } \\
\text { the mucosa }\end{array}$ & $\begin{array}{l}\text { inflammatory cells } \\
\text { infiltration of the } \\
\text { submucosa and the } \\
\text { bottom half of the } \\
\text { mucosa }\end{array}$ & $\begin{array}{l}\text { inflammatory cells } \\
\text { infiltration of the } \\
\text { submucosa and } \\
\text { greater than } 50 \% \\
\text { of the mucosa }\end{array}$ & $\begin{array}{l}\text { transmural infiltration } \\
\text { of inflammatory cells }\end{array}$ \\
\hline $\begin{array}{l}\text { Epithelial } \\
\text { defects }\end{array}$ & $\begin{array}{l}\text { no visible parietal cell } \\
\text { and chief cell loss }\end{array}$ & $\begin{array}{l}25 \% \text { parietal cell } \\
\text { loss and } 50 \% \text { chief } \\
\text { cell loss }\end{array}$ & $\begin{array}{l}50 \% \text { parietal cell } \\
\text { loss and greater } \\
\text { than } 75 \% \text { chief cell } \\
\text { loss }\end{array}$ & $\begin{array}{l}75 \% \text { parietal cell } \\
\text { loss and } 100 \% \\
\text { chief cell loss }\end{array}$ & $\begin{array}{l}\text { greater than } 75 \% \\
\text { parietal cell loss and no } \\
\text { chief cells }\end{array}$ \\
\hline $\begin{array}{l}\text { Mucous } \\
\text { metaplasia }\end{array}$ & $\begin{array}{l}\text { no visible mucus } \\
\text { metaplasia }\end{array}$ & $\begin{array}{l}\text { small foci were } \\
\text { present }\end{array}$ & $\begin{array}{l}\text { up to one-third of } \\
\text { the parietal cells } \\
\text { was affected }\end{array}$ & $\begin{array}{l}\text { two thirds of the } \\
\text { parietal cells were } \\
\text { affected }\end{array}$ & $\begin{array}{l}\text { greater than two thirds } \\
\text { of the parietal cells } \\
\text { were affected }\end{array}$ \\
\hline $\begin{array}{l}\text { Intestinal } \\
\text { metaplasia }\end{array}$ & $\begin{array}{l}\text { no visible mucus } \\
\text { metaplasia }\end{array}$ & $\begin{array}{l}\text { small foci were } \\
\text { present }\end{array}$ & $\begin{array}{l}\text { up to one-third } \\
\text { of the corpus was } \\
\text { affected }\end{array}$ & $\begin{array}{l}\text { two thirds of } \\
\text { the corpus were } \\
\text { affected }\end{array}$ & $\begin{array}{l}\text { greater than two thirds } \\
\text { of the corpus were } \\
\text { affected }\end{array}$ \\
\hline Dysplasia & no visible dysplasia & $\begin{array}{l}\text { appearing aberrant } \\
\text { crypt foci including } \\
\text { distortion of } \\
\text { normal columnar } \\
\text { orientation, } \\
\text { increased diameter, } \\
\text { asymmetrical cell } \\
\text { piling, and back-to- } \\
\text { back forms }\end{array}$ & $\begin{array}{l}\text { there is glandular } \\
\text { infolding, } \\
\text { branching, and } \\
\text { more advanced } \\
\text { cellular atypia } \\
\text { such as increased } \\
\text { nuclear- } \\
\text { cytoplasmic ratio }\end{array}$ & $\begin{array}{l}\text { cellular distortion } \\
\text { with haphazard } \\
\text { arrangements, the } \\
\text { lesion developed to } \\
\text { carcinoma in situ }\end{array}$ & $\begin{array}{l}\text { highly dysplastic } \\
\text { glands invade into the } \\
\text { submucosa or beyond, } \\
\text { such as deeper layers, } \\
\text { vessels and lymphatics }\end{array}$ \\
\hline
\end{tabular}

mice combined with loss of other tumor suppressors $[13,22]$. We were interested in whether haploid loss of Fbxw7 would increase the gastric carcinogenesis. So we treated the Fbxw7 heterozygous knockout mice with chemical carcinogen MNU. By our research, Fbxw7 heterozygotes had higher susceptibilities to gastric cancer after MNU exposure, compared to wild-type mice. Fbxw7 expression was reduced in $\mathrm{Fbxw} 7^{+/-}$mice than in controls, but none of tumors from $\mathrm{Fbxw} 7^{+/-}$mice showed lost Fbxw7 expression, which meant all mice maintained Fbxw7 expression of the retained one allele. Our results were consistent with previous reports on other types of cancer [13, 31, 32]. The results support that Fbxw7 haploinsufficiency increases the gastric cancer risk. Then we used Ki67 staining and TUNEL assay to examine the proliferation and apoptosis in tumors from $\mathrm{Fbxw} 7^{+/-}$mice. Our results showed that cell apoptosis was significantly decreased in tumors from $\mathrm{Fbxw} 7^{+/-}$mice, consistent with previous reports that Fbxw7 overexpression induced apoptosis [6].

To understand the molecular mechanisms of Fbxw7 haploinsufficiency on gastric carcinogenesis, we examined the expression of oncoprotein $\mathrm{c}-\mathrm{Myc}$, which had been noticed as a substrate of FBXW7 protein [7, 8, 33]. We compared the protein expression levels of Fbxw7 and $\mathrm{c}$-Myc and confirmed the reverse expressing relation of these two proteins by Western blot. The protein level of Fbxw7 expression was lower in $\mathrm{Fbxw} 7^{+/}$mice, compared with controls, while c-Myc showed the opposite change, especially in tumors. Fbxw7 haploinsufficiency resulted in decreased Fbxw7 expression and increased c-Myc expression. Considering the role of c-Myc in promoting cell transformation, this may be one of the reasons why Fbxw $7^{+/-}$mice developed more gastric tumors than controls (Figure 7).

Fbxw7 has been reported to be related with DNA damage repair and play its role via K63 linkage, which is completely different from ubiquitin protease degradation system. In order to clarify the role of Fbxw7 haploinsufficiency in gastric carcinogenesis, we used MEFs from Fbxw $7^{+/-}$and Fbxw $7^{+/+}$mice to examine the reaction of these two cells to MNU treatment. With the development of genetically engineered mice, MEFs from specific gene mutated mice (deletion of one allele or both) have been cultured and used to study the impacts of the heterozygous or null mutated gene. Mao, et al. subjected MEFs from $\mathrm{p} 53^{+/-}, \mathrm{p} 53^{-/-}$and wild-type mice to $\gamma$-radiation and examined whether activation of $\mathrm{p} 53$ by radiation might have an effect on the expression of Fbxw7. They found the increase of Fbxw7 mRNA was dependent on p53 activation [13]. Dai, et al. used MEFs from BubR1 ${ }^{+/-}$ mice to determine the expression of BubR1 and its 
Ai

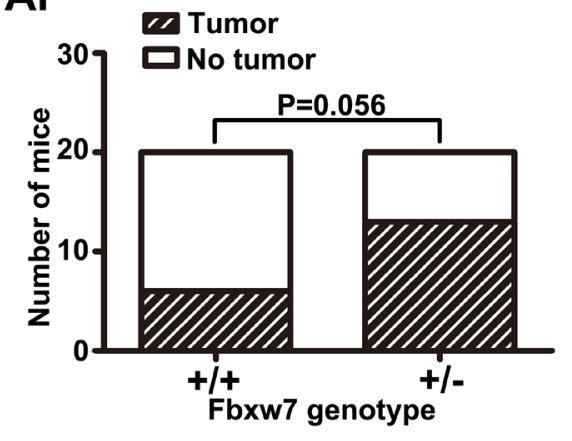

B

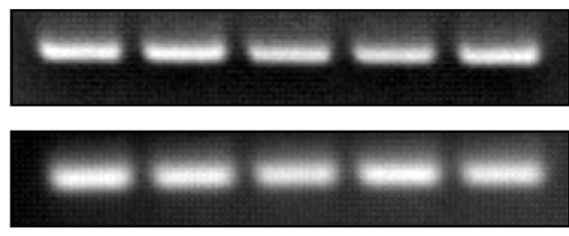

$$
+/-+/-+/-\quad+/-\quad+/-
$$

Aii

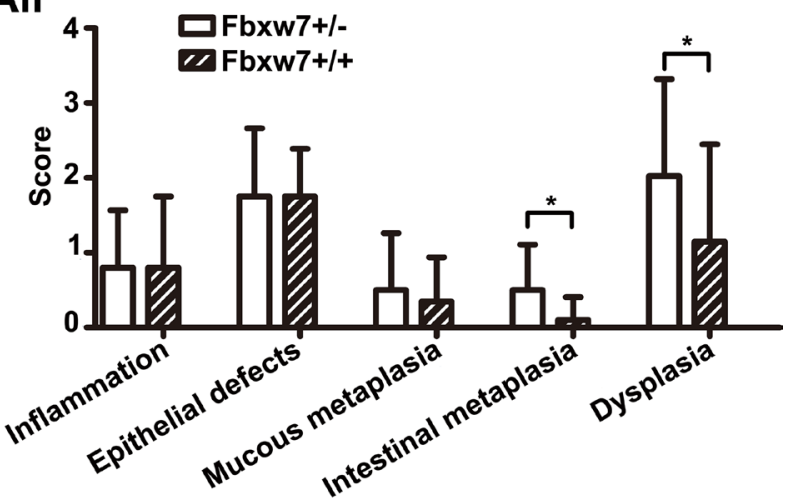

Fbxw7

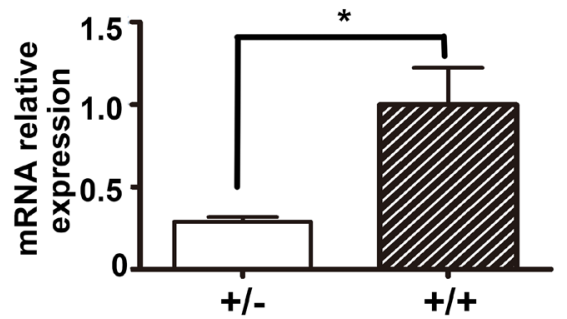

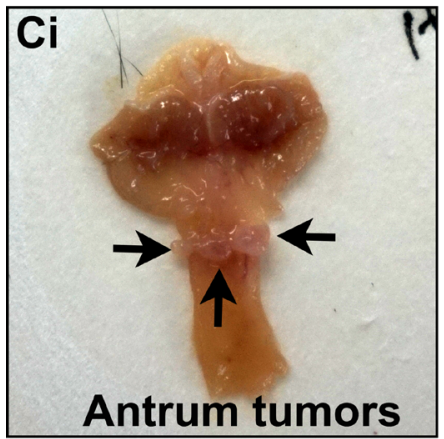
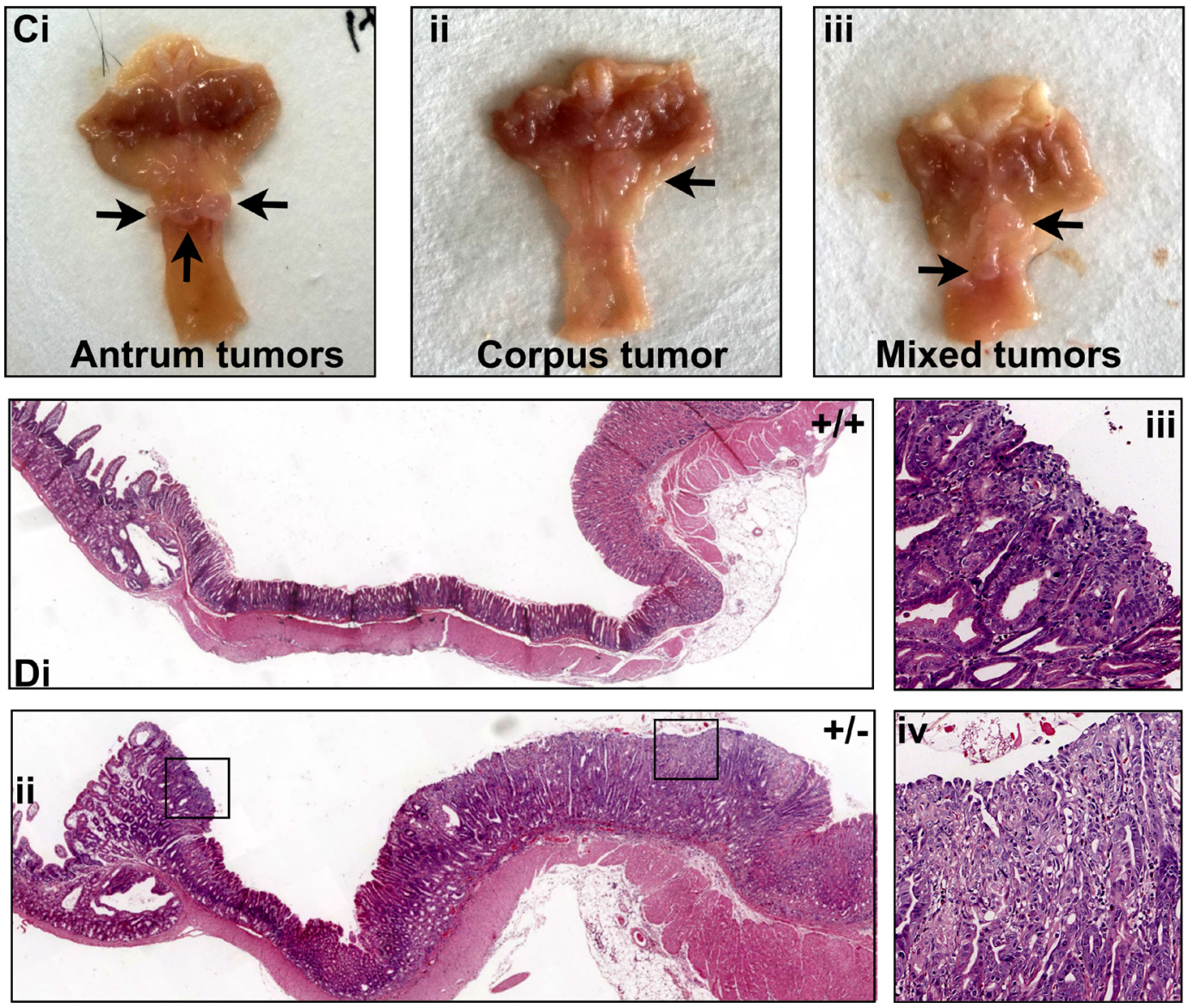

Figure 2: Induction of gastric tumor development in the antrum in $\mathrm{Fbxw}^{+/-}$mice. (A) Incidence (Ai) and pathological score (Aii) of gastric tumor formation in $\mathrm{Fbxw} 7^{+/}$and $\mathrm{Fbxw} 7^{7^{+/}}$mice at the age of 35 weeks with MNU-based treatment $(n=20$ each genotype). (B) mRNA expression of Fbxw7 from tumors of $\mathrm{Fbxw}^{+/-}$mice ( $n=5$ each genotype, left figure is from the semi-quantitative examination, and right figure is from the real-time RT-PCR assay). (C) Gross morphology of visible tumors (black arrows) in the gastric antrum (Ci), corpus (Cii), or both ("mixed", Ciii) in Fbxw $7^{+/}$mice enlarged. (D) Representative photographs of macroscopic views of the entire gastric mucosa in $\mathrm{Fbxw}^{7^{+/}}$(Di) and Fbxw $7^{+/-}$(Dii) mice and two microscopic view of an gastric tumor in the Fbxw $7^{+/-}$mouse (Diii, Div). The 2-tailed $X^{2}$ test was used to determine the significance of the tumor incidence. The non-parametric test was used to determine the significance of the difference between pathological scores of each group. “*” refers to statistically significant $(P<0.05)$. 
activation after microtubule disruption, and found that ablation of one BubR1 allele reduced the expression and activation of the other allele [34]. All above-mentioned studies demonstrate that MEFs originated from gene knockout mice lacking one or both alleles at DNA levels have unique advantages in in-vitro research, especially in heterozygous mutation study. So we analyzed the effect of Fbxw7 haploinsufficiency on cultured MEFs from $\mathrm{Fbxw}^{+/-}$and $\mathrm{Fbxw} 7^{+/+}$mice after MNU exposure.
MNU is one of the alkylating agents and widely used in gastric carcinogenesis study [35]. MNU directly alkylates nitrogen and oxygen atoms of DNA bases, resulting in single nucleotide mutations and DNA strand breaks [36]. Regarding to DNA damage, H2AX will be recruited and phosphorylated at DNA damage site. So, $\mathrm{pH} 2 \mathrm{AX}$ appears at damage sites in early stage, and is considered as a sensitive biomarker for DNA damage $[37,38]$. We treated MEFs with $0.5 \mathrm{mM} \mathrm{MNU}$ as
A
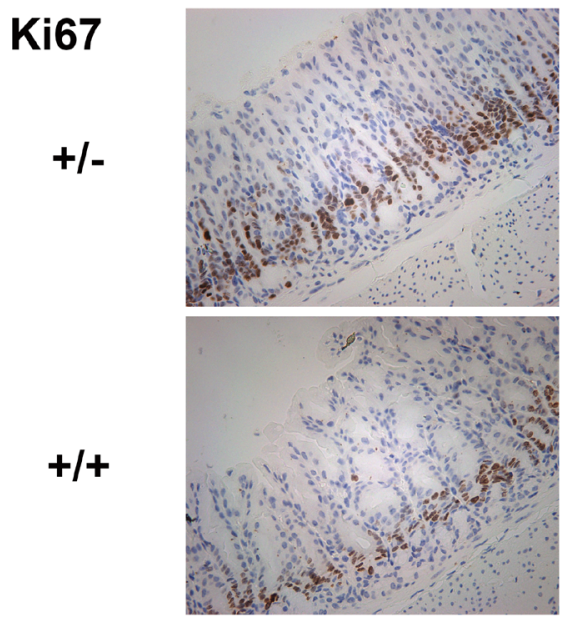

Bunel

$+1-$
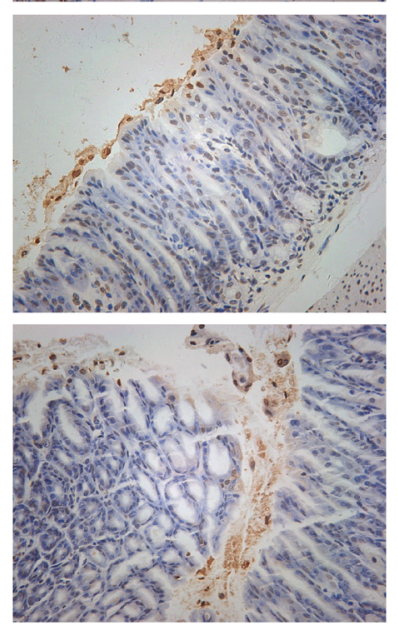

hyperplasia
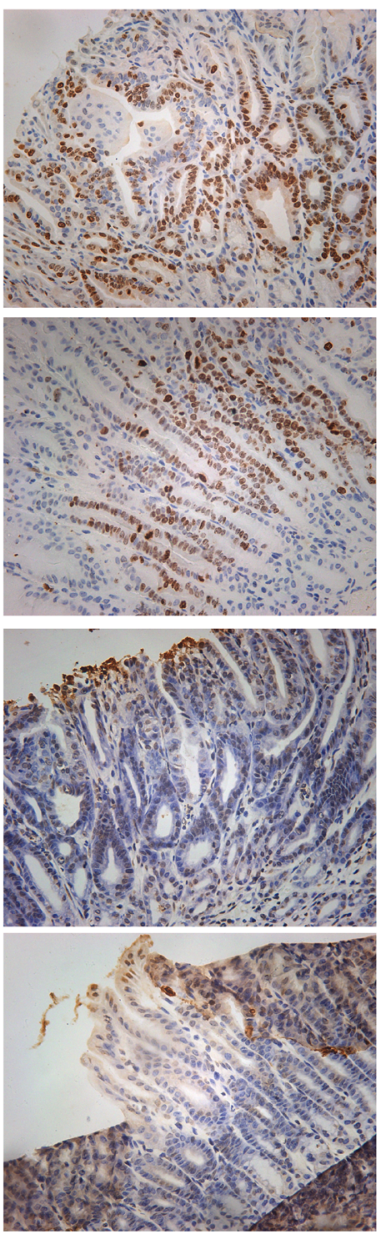

\section{neoplasia}
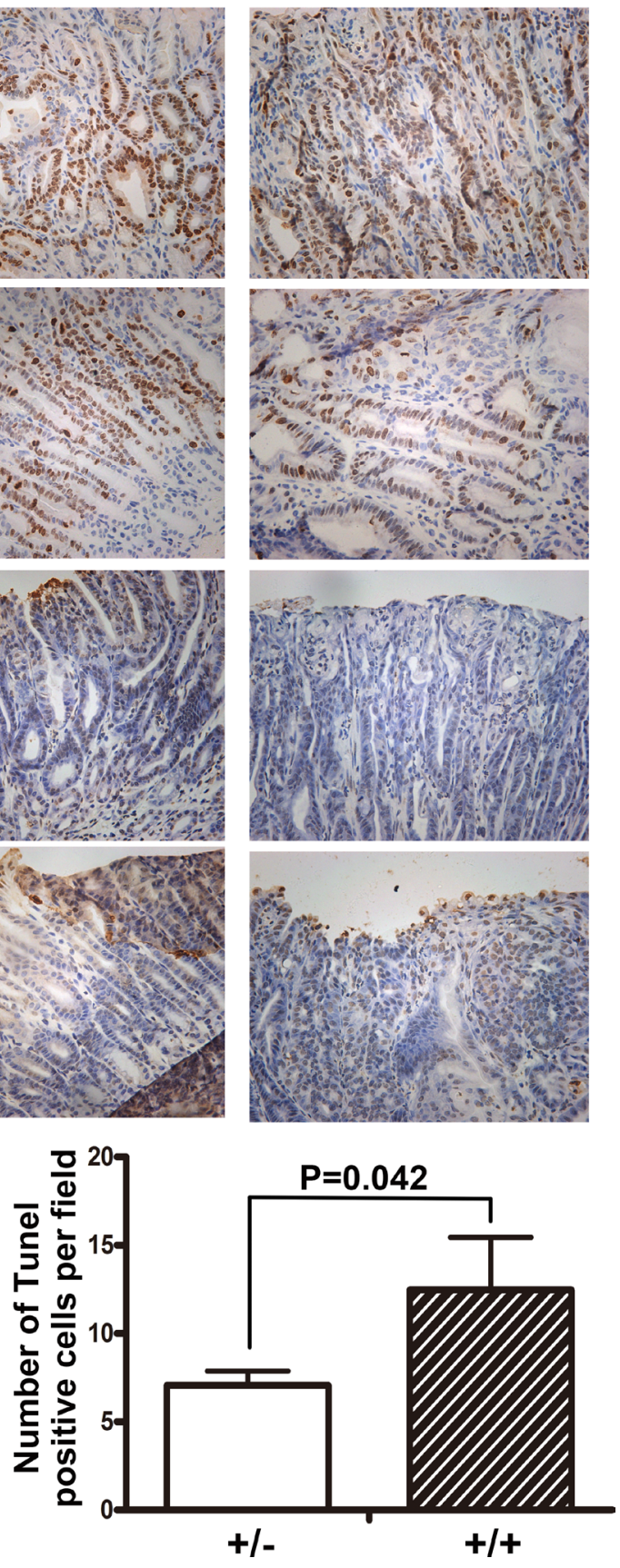

Figure 3: Immunohistochemistry staining of Ki67 and TUNEL in antrum. Sections of antral tissues were prepared from $\mathrm{Fbxw}^{+/-}$and $\mathrm{Fbxw}^{+/+}$mice. From left to right were: normal, hyperplastic and neoplastic tissues. Cell proliferation was determined by Ki67 staining. Cell apoptosis was determined by TUNEL. The $X^{2}$ or $T$ test was used to determine the significance of Ki67 and TUNEL studies. 
reported [39], and detected $\mathrm{pH} 2 \mathrm{AX}$ expression by immunofluorescence. Moreover, since comet assay is a rapid and sensitive method for detecting DNA damage in living cells [40, 41], we also analyzed DNA damage of MEFs cells by comet assay. The results showed delayed DNA repair in $\mathrm{Fbxw}^{+/-}$mice, suggesting that insufficiency of Fbxw7 disturbs the genomic stability and increases DNA damage. Generally, the damaged cells would result in apoptosis to maintain genomic stability. However, the cell apoptosis was decreased in $\mathrm{Fbxw}^{+/-}$mice, leading to the DNA damage accumulated (Figure 7). To our knowledge, our research firstly clarified the association of DNA damage with Fbxw7 haploinsufficiency based on MNU exposure. Haploinsufficiency of tumor suppressor, such as H2AX, Tip60 and BubR1, have also been reported to involve in genomic instability and accelerated tumorigenesis through direct or indirect participation in DNA damage repair [42-44]. Fbxw7 was reported to
A Control

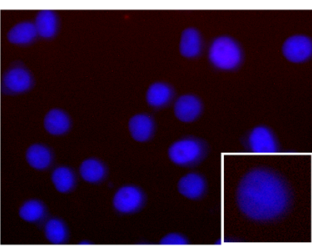

Fbxw7+/+
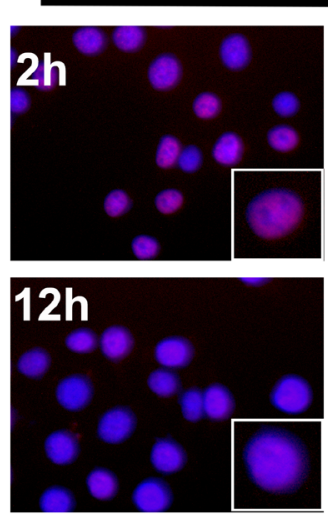

B Control

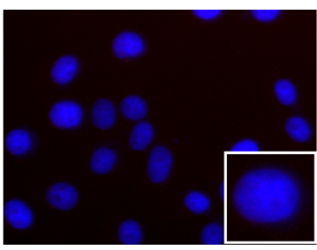

Fbxw7+/-
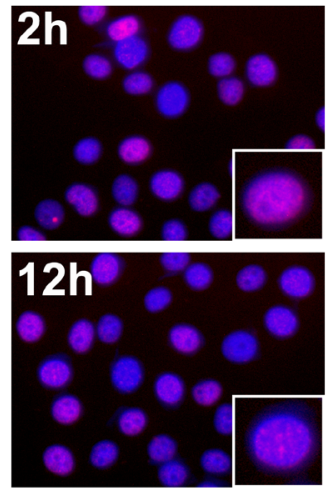

MNU
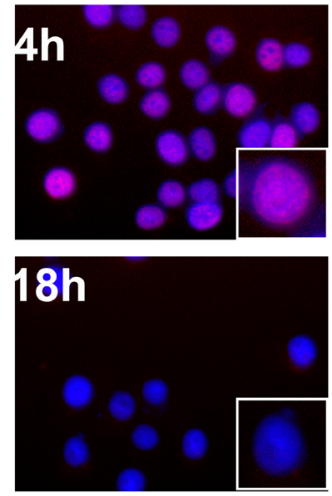

MNU
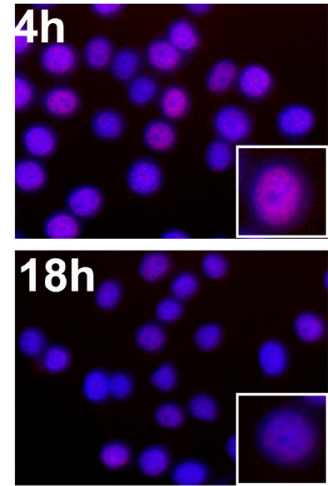
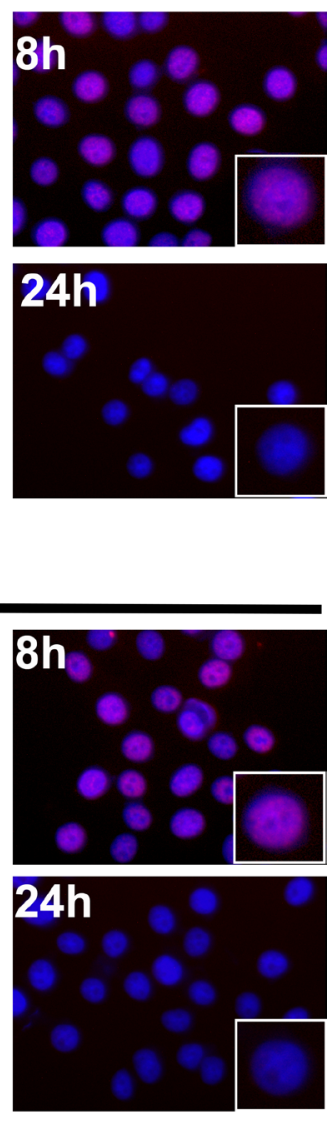
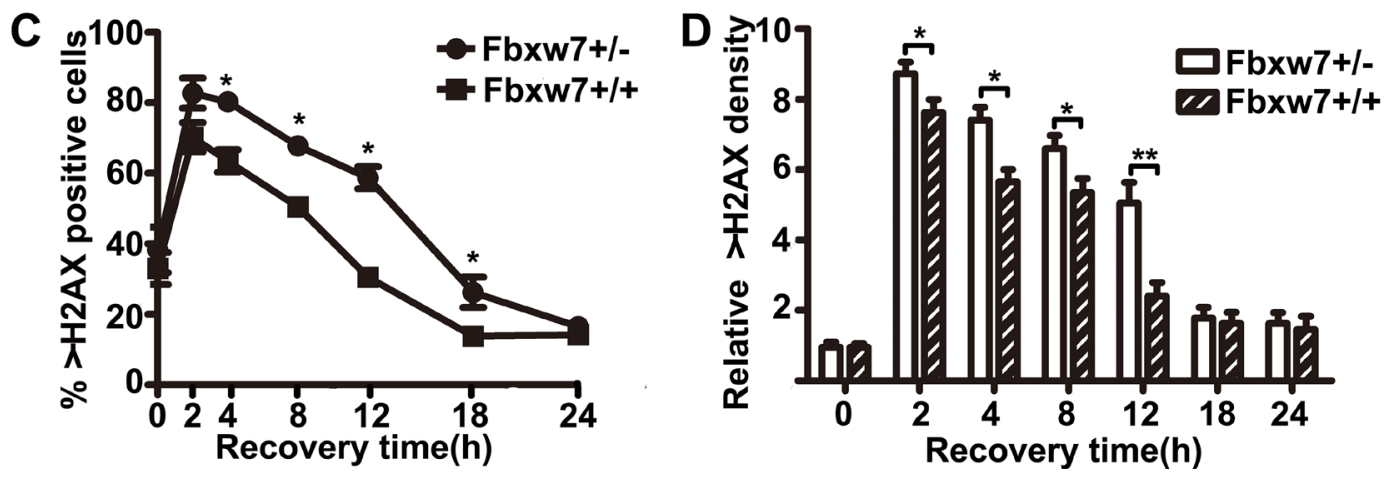

Figure 4: Bimodal pattern of $\mathrm{H} 2 \mathrm{AX}$ phosphorylation after treatment with MNU. (A, B) $\mathrm{pH} 2 \mathrm{AX}$ foci in $\mathrm{MEFs}$ from Fbxw $7^{+/+}$ (A) and $\mathrm{Fbxw}^{+/-}$(B) after MNU treatment. The cells were collected and fixed at the indicated time points after treatment. (C, D) The dynamics of $\mathrm{pH} 2 \mathrm{AX}$ foci formation after treatment as shown in (A) and (B). Data are presented as mean $\pm \mathrm{SD}$, from three independent experiments. The $X^{2}$ or $T$ test was used to determine the significance of $\mathrm{pH} 2 \mathrm{AX}$ positive incidence and intensity. "*" refers to statistically significant $(P<0.05)$. 
modulate genomic instability dependent on XRCC4 and cyclin E $[12,14]$. It seems that Fbxw7 haploinsufficiency affects DNA damage repair through an indirect way. However, further studies are required to reveal the detailed mechanism behind this effect.

In summary, the present study demonstrates that Fbxw7 haploinsufficiency is associated with increased tumorigenesis in stomach, which may depend on dysregulated c-Myc degradation and DNA damage repair. The mouse model of Fbxw7 haploinsufficiency is a useful tool for gastric carcinogenesis study, especially for intestinal-type gastric cancer study.

\section{MATERIALS AND METHODS}

\section{Mouse models}

The ES cells harboring the mutant Fbxw7 allele were bought from European Conditional Mouse Mutagenesis Program (EUCOMM) (http://www.
A Control

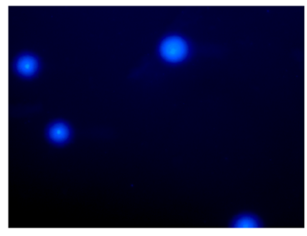

Fbxw7+l+
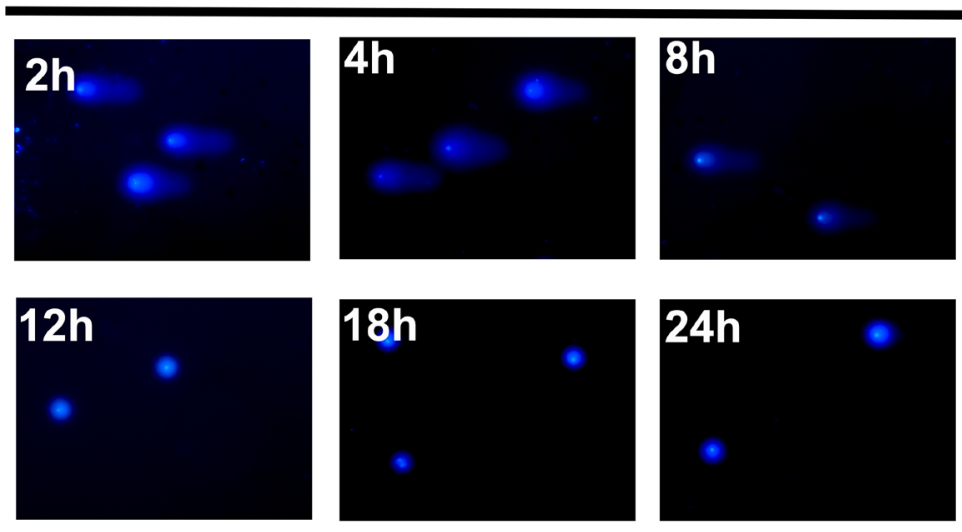

B
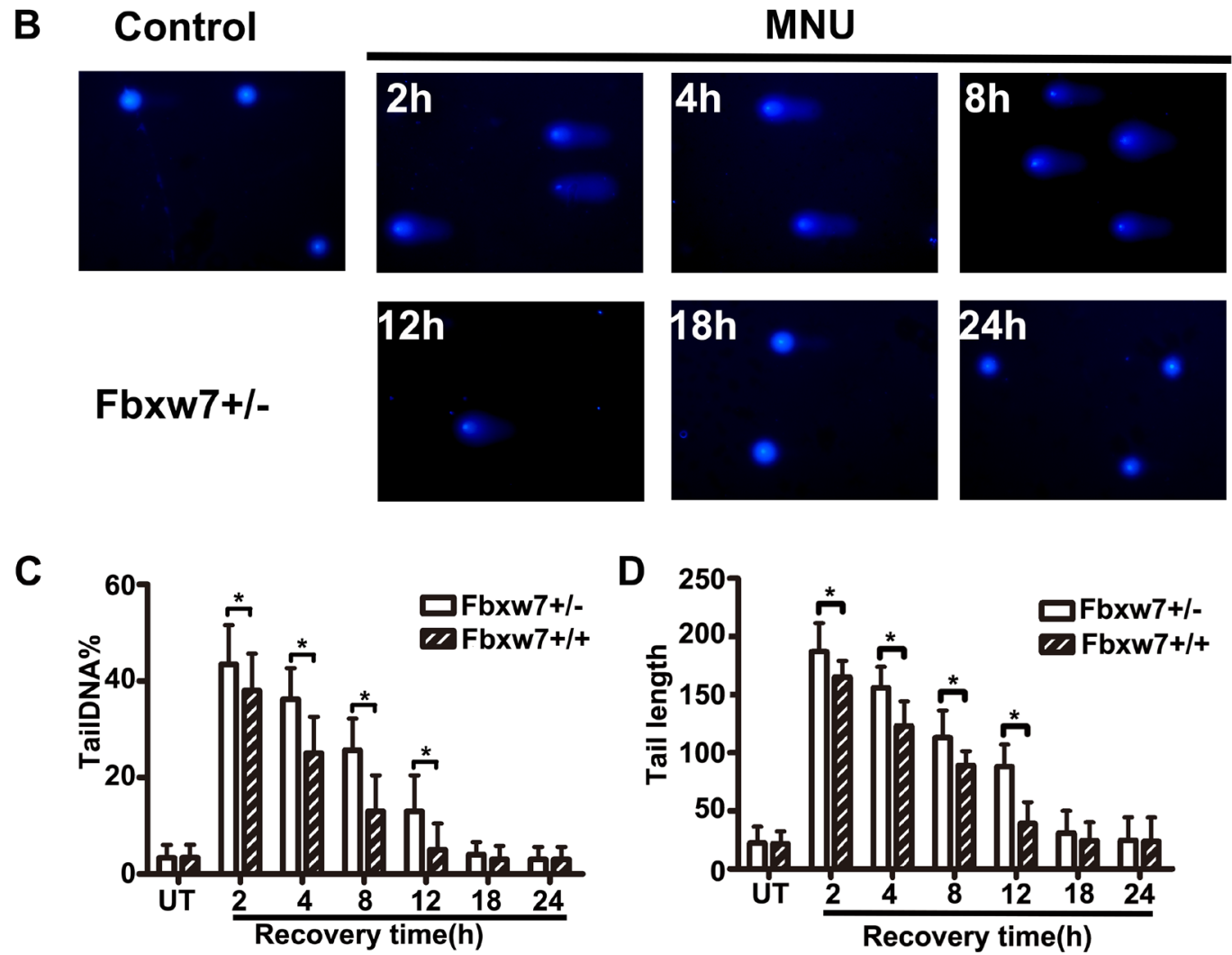

Figure 5: Detection of DNA damage by comet assay. (A, B) The comet images of MEFs from $\mathrm{Fbxw} 7^{+/+}(\mathrm{A})$ and $\mathrm{Fbxw} 7^{+/-}$ (B) at given time after MNU treatment. (C, D) The repair kinetics of DNA damage, which were expressed as the comets tailDNA\% (C) and tail length (D). The data are the means and standard deviation from three experiments, and more than 50 comets were analyzed in each experiment. The $T$ test was used to determine the significance of comet assay. "*” refers to statistically significant $(P<0.05)$. 
knockoutmouse.org/martsearch/project/27275) and transferred to the blastocoel cavities of 3.5 day blastocyst embryos. The embryos were transferred to surrogate mothers where gestation was completed. Then we crossed the chimeric founders with wild type C57BL/6 mice to generate heterozygous Fbxw7 knockout mice. Genomic DNA was extracted from mouse tail and assayed for the presence of Fbxw7-flox by polymerase chain reaction (PCR) with the following primers: loxP-F, 5'-GTTGAAATGCTTCGCTCGTTTGC-3'; loxP-R, 5'-CTGATGGCGAGCTCAGACCATAACT-3'; control-R, 5'-TGCCGTGTAACAGGCGTGCTAT-3'.

\section{Chemical-induced carcinogenesis by $\mathrm{N}$-methyl- N-nitrosourea}

The alkylating agent N-methyl-N-nitrosourea (MNU, Sigma, USA) was dissolved in distilled water at $240 \mathrm{mg} / \mathrm{L}$, and freshly prepared 3 times per week for administration to the mice in drinking water in lightshielded bottles. 40 mice of 5 to 6 weeks old $\left(20 \mathrm{Fbxw}^{+/-}\right.$ mice and $20 \mathrm{Fbxw} 7^{+/+}$mice) were used. These mice were exposed to MNU-contained drinking water every two weeks for a total of 5 weeks exposure. All mice were around 35 weeks of age at sacrifice.

\section{Protein expression detection of Fbxw7 and associated genes}

The protein lysates were prepared from collected cells in lysis buffer containing $20 \mathrm{mM}$ Hepes, $0.15 \mathrm{M} \mathrm{NaCl}$ and $1 \%$ Triton X-100 supplemented phosphatase inhibitor and protease inhibitor cocktail. Proteins were quantified by BCA, with bovine serum albumin as control. Proteins were separated by $10 \%$ sodium dodecyl sulfate polyacrylamide gel electrophoresis. PVDF membranes were incubated with the following antibodies: FBXW7-antibody (1:1000, Abcam, ab109617), c-Myc antibody (1:1000, Santa Cruz,

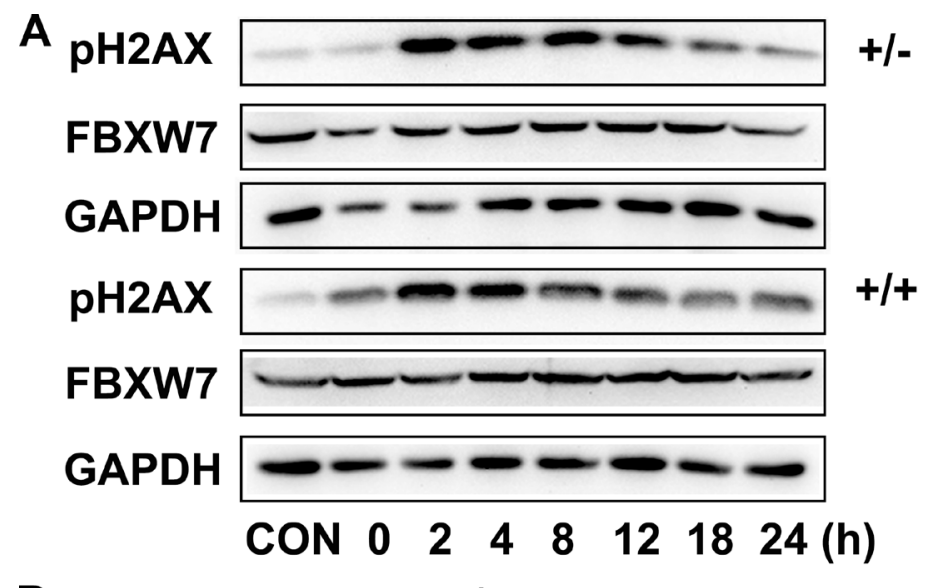

B

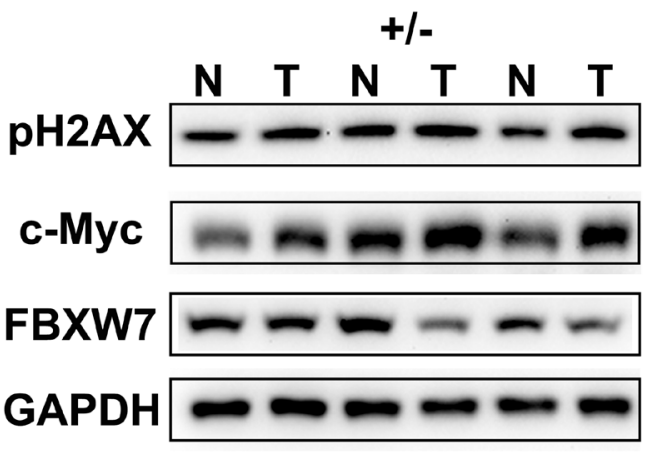

C
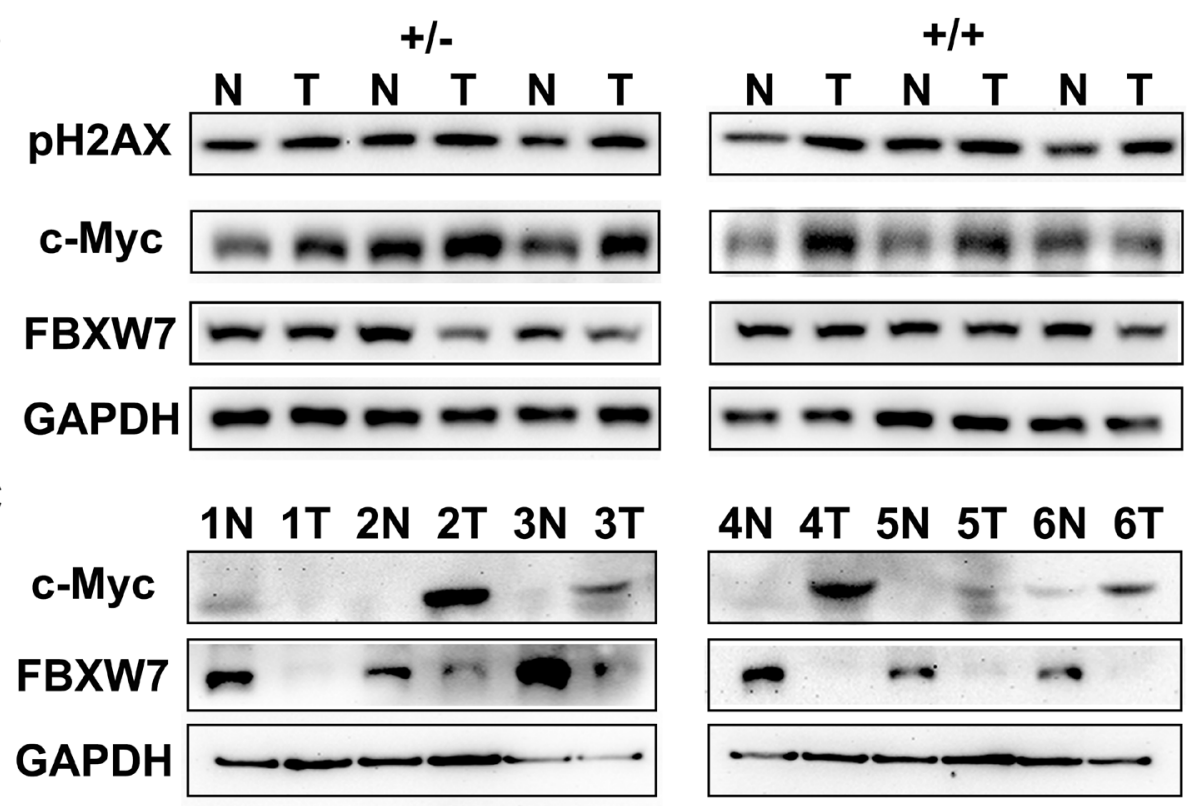

Figure 6: Loss of Fbxw7 expression and overexpression of c-Myc in gastric cancer. (A) Western blot for pH2AX expression at indicated time points after MNU treatment (left). Genotyping and microscopic view of Fbxw $7^{+/+}$and Fbxw $7^{+/-} \mathrm{MEFs}$ (right). (B, C) Western blot analyses were performed using total protein lysates extracted from antral mucosa from mice (B) and from patients (C). 
9e10), pH2AX antibody (1:1000, CST, \#9718). GAPDH antibody was used for internal control.

\section{Detection of DNA damage on MEFs}

MNU stock solution (50mM) was prepared freshly in dimethyl sulfoxide (DMSO) and diluted in PBS to a final DMSO concentration of $1 \%$. Mouse embryo fibroblasts (MEFs) were extracted from E15.5d Fbxw $7^{+/-}$and Fbxw $7^{+/+}$mice and seeded in 6-well dishes $\left(2 \times 10^{5}\right.$ cells $\left./ \mathrm{ml}\right)$. After $24 \mathrm{~h}$ cultivation, the cells were exposed to $0.5 \mathrm{mM} \mathrm{MNU}$ in PBS for $30 \mathrm{~min}$, and suspended in fresh growth medium. The comet assays were performed after $0 \mathrm{~h}, 2 \mathrm{~h}, 4 \mathrm{~h}, 8 \mathrm{~h}, 12 \mathrm{~h}, 18 \mathrm{~h}$ and $24 \mathrm{~h}$ of recovery at $37^{\circ} \mathrm{C}$, with Trevigen Comet Assay ${ }^{\mathrm{TM}}$ kit (Trevigen Inc., Gaithersburg, MD, USA). Cells were resuspended in ice cold $\mathrm{PBS}\left(\mathrm{Ca}^{2+}\right.$ and $\mathrm{Mg}^{2+}$ free $)$ to a concentration of $1 \times 10^{5} \mathrm{cells} / \mathrm{ml}$. An aliquot of $50 \mu \mathrm{l}$ of cells $\left(1 \times 10^{5}\right.$ cells $\left./ \mathrm{ml}\right)$ was added to $500 \mu$ of molten LM agarose $\left(1 \%\right.$ low-melting agarose) kept at $42^{\circ} \mathrm{C}$. Fifty microliters were immediately pipetted and evenly spread onto an area of the comet slides. The slides were incubated at $4^{\circ} \mathrm{C}$ in the dark for $10 \mathrm{~min}$ to accelerate gelling of the agarose disc and then transferred to prechilled lysis solution for $60 \mathrm{~min}$ at $4^{\circ} \mathrm{C}$. A denaturation step was performed in $200 \mathrm{mM} \mathrm{NaOH}$ alkaline solution $(1 \mathrm{mM}$ EDTA, $\mathrm{pH}>13$ ) at room temperature for $20 \mathrm{~min}$ in the dark. The slides were subjected to electrophoresis at $1 \mathrm{~V} / \mathrm{cm}, 300 \mathrm{~mA}$ for $30 \mathrm{~min}$ in the dark at $4^{\circ} \mathrm{C}$. At the end of the electrophoresis, the slides were washed with $\mathrm{dH}_{2} \mathrm{O}$ for $5 \mathrm{~min}$, and immersed in $70 \%$ ethanol for $5 \mathrm{~min}$ and air dried. DNA was stained with $50 \mu$ DAPI (1:1000 in TrisEDTA buffer, $\mathrm{pH} \mathrm{7.5)} \mathrm{for} 20 \mathrm{~min}$ in the refrigerator and immediately analyzed using fluorescence microscope. The tailDNA $\%$ and tail length were measured as DNA damage parameters. At least 50 cells were analyzed per sample.

\section{Immunohistochemistry and TUNEL}

Mouse stomach was cut and unfolded along the greater curvature, and fixed in $4 \%$ formaldehyde solution. The $4 \mu \mathrm{m}$ paraffin-embedded sections were deparaffinized and rehydrated for further immunohistochemical staining, with Ki67 antibody (1:100; Abcam) and Dako twostep detection Kit (Dako, CA, USA). The slides were counterstained with hematoxylin and viewed with light

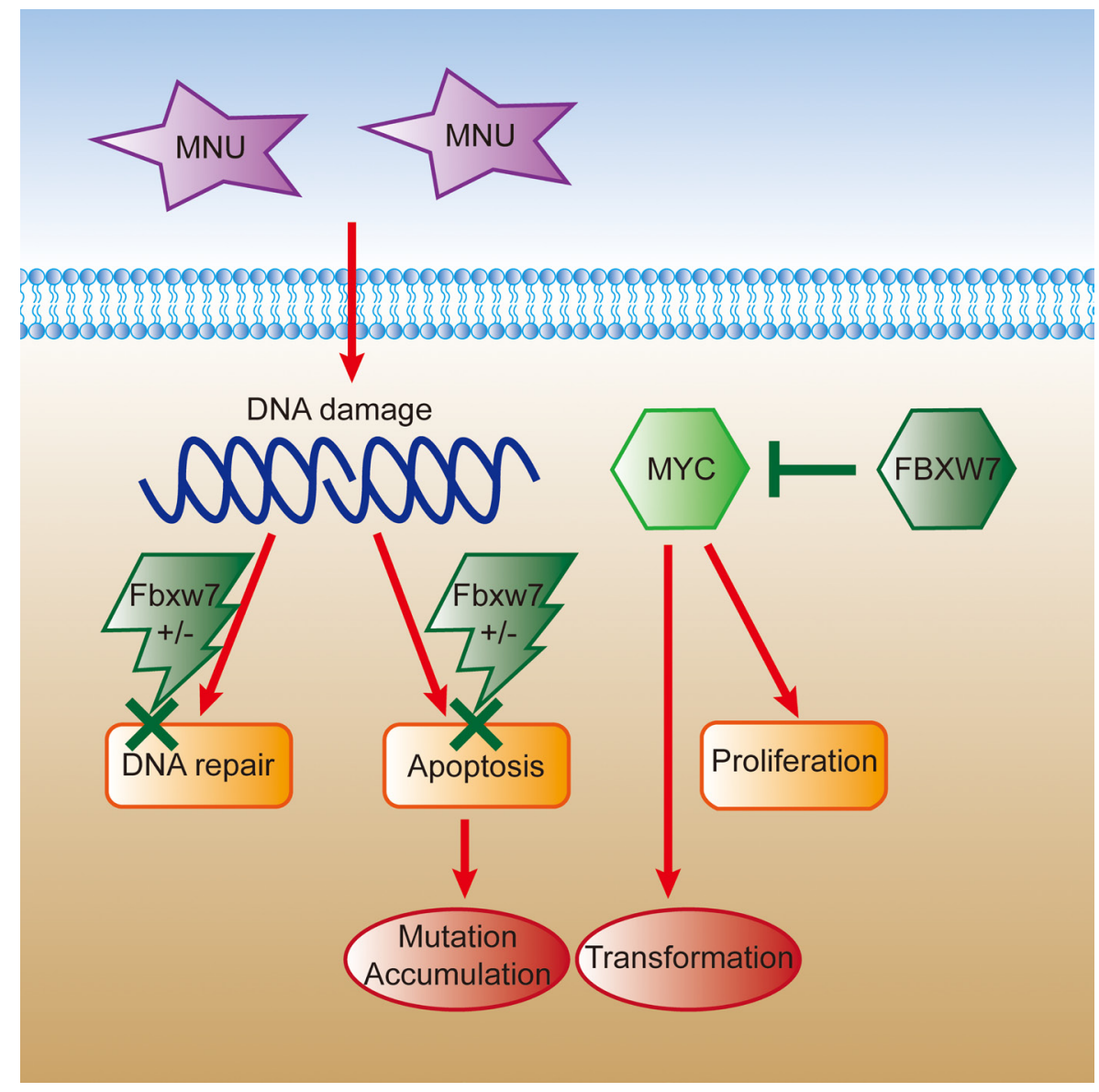

Figure 7: The schematic figure of somatic cells transformation induced by MNU in Fbxw7 haploinsufficiency condition. Cell DNA is damaged under the MNU exposure. Due to the haploinsufficiency of Fbxw7, it is difficult to repair mutated DNA as well as proceed apoptosis. Meanwhile, insufficient FBXW7 level results in elevated downstream c-MYC expression and promoted cell transformation and proliferation. 
microscope. TUNEL assay was carried out according to the instructions (TUNEL Assay Kits for Apoptosis Detection, Roche). Five samples for each genotype and 10 fields per sample were observed

\section{Immunofluorescence}

The MEFs cells $\left(2 \times 10^{5}\right.$ cells $\left./ \mathrm{ml}\right)$ from $\mathrm{Fbxw} 7^{+/-}$ and $\mathrm{Fbxw} 7^{+/+}$mice were grown and treated in 24-well dishes. Following $24 \mathrm{~h}$ cultivation, the cells were exposed to $0.5 \mathrm{mM} \mathrm{MNU}$ in PBS for $30 \mathrm{~min}$, and suspended in fresh growth medium. The cells were fixed in $4 \%$ paraformaldehyde and stained with $\mathrm{pH} 2 \mathrm{AX}$ antibody (1:100, CST, \#9718), and counterstained by DAPI. The slides were observed under the fluorescent microscope. At least 100 cells from each treatment condition were scored.

\section{Statistical analysis}

The 2-tailed $X^{2}$ test was used to determine the significance of the tumor incidence in each group. The non-parametric test was used to determine the significance of the difference between pathological scores of each group. The $X^{2}$ or $T$ test was used to determine the significance of $\mathrm{pH} 2 \mathrm{AX}$ positive incidence and intensity. The $T$ test was used to determine the significance of comet assay. In all tests, $P<0.05$ was considered statistically significant. The SPSS software program (version 19.0; SPSS Inc., Chicago, IL, USA) was used for the statistical analysis.

\section{ACKNOWLEDGMENTS AND FUNDING}

This project was partially supported by the Chinese National Key Program (2016YFC1303202, 2012AA02A504, 2012AA02A203), the National Natural Science Foundation of China (81372644), Project of Shanghai Science and Technology Commission (11XD1403600 and 12410706400), the Innovation Foundation of Translational Medicine of Shanghai Jiao Tong University School of Medicine (15ZH1002, 15ZH400, TM201617), the "Personalized Medicines_-Molecular Signature-based Drug Discovery and Development", Strategic Priority Research Program of the Chinese Academy of Sciences (XDA12020339) and the National Science and Technology Major Project (2015ZX09102005).

\section{CONFLICTS OF INTEREST}

None.

\section{REFERENCES}

1. Ferlay J, Soerjomataram I, Dikshit R, Eser S, Mathers C, Rebelo M, Parkin DM, Forman D, Bray F. Cancer incidence and mortality worldwide: Sources, methods and major patterns in GLOBOCAN 2012. International journal of cancer Journal international du cancer. 2015; 136:E359-386.

2. Wang $Z$, Inuzuka $H$, Zhong J, Wan L, Fukushima H, Sarkar FH, Wei W. Tumor suppressor functions of FBW7 in cancer development and progression. FEBS letters. 2012; 586:1409-1418.

3. Tan Y, Sangfelt O, Spruck C. The Fbxw7/hCdc4 tumor suppressor in human cancer. Cancer letters. 2008; 271:1-12.

4. Welcker M, Clurman BE. FBW7 ubiquitin ligase: a tumour suppressor at the crossroads of cell division, growth and differentiation. Nature reviews Cancer. 2008; 8:83-93.

5. Cheng Y, Li G. Role of the ubiquitin ligase Fbw7 in cancer progression. Cancer metastasis reviews. 2012; 31:75-87.

6. Li H, Wang Z, Zhang W, Qian K, Xu W, Zhang S. Fbxw7 regulates tumor apoptosis, growth arrest and the epithelialto-mesenchymal transition in part through the RhoA signaling pathway in gastric cancer. Cancer letters. 2016; 370:39-55.

7. Milne AN, Leguit R, Corver WE, Morsink FH, Polak M, de Leng WW, Carvalho R, Offerhaus GJ. Loss of CDC4/ FBXW7 in gastric carcinoma. Cellular oncology. 2010; 32:347-359.

8. Calcagno DQ, Freitas VM, Leal MF, de Souza CR, Demachki S, Montenegro R, Assumpcao PP, Khayat AS, Smith Mde A, dos Santos AK, Burbano RR. MYC, FBXW7 and TP53 copy number variation and expression in gastric cancer. BMC gastroenterology. 2013; 13:141.

9. Akhoondi S, Sun D, von der Lehr N, Apostolidou S, Klotz K, Maljukova A, Cepeda D, Fiegl H, Dafou D, Marth C, Mueller-Holzner E, Corcoran M, Dagnell M, et al. FBXW7/hCDC4 is a general tumor suppressor in human cancer. Cancer research. 2007; 67:9006-9012.

10. Davis RJ, Welcker M, Clurman BE. Tumor suppression by the Fbw7 ubiquitin ligase: mechanisms and opportunities. Cancer cell. 2014; 26:455-464.

11. Wang Z, Liu P, Inuzuka H, Wei W. Roles of F-box proteins in cancer. Nature reviews Cancer. 2014; 14:233-247.

12. Rajagopalan H, Jallepalli PV, Rago C, Velculescu VE, Kinzler KW, Vogelstein B, Lengauer C. Inactivation of hCDC4 can cause chromosomal instability. Nature. 2004; 428:77-81.

13. Mao JH, Perez-Losada J, Wu D, Delrosario R, Tsunematsu R, Nakayama KI, Brown K, Bryson S, Balmain A. Fbxw7/Cdc4 is a p53-dependent, haploinsufficient tumour suppressor gene. Nature. 2004; 432:775-779.

14. Zhang Q, Karnak D, Tan M, Lawrence TS, Morgan MA, Sun Y. FBXW7 Facilitates Nonhomologous End-Joining via K63-Linked Polyubiquitylation of XRCC4. Molecular cell. 2016; 61:419-433.

15. Sherr CJ. Principles of tumor suppression. Cell. 2004; 116:235-246.

16. Francis JM, Kiezun A, Ramos AH, Serra S, Pedamallu CS, Qian ZR, Banck MS, Kanwar R, Kulkarni AA, Karpathakis A, 
Manzo V, Contractor T, Philips J, et al. Somatic mutation of CDKN1B in small intestine neuroendocrine tumors. Nature genetics. 2013; 45:1483-1486.

17. Kumar MS, Pester RE, Chen CY, Lane K, Chin C, Lu J, Kirsch DG, Golub TR, Jacks T. Dicer1 functions as a haploinsufficient tumor suppressor. Genes \& development. 2009; 23:2700-2704.

18. Ying $\mathrm{H}$, Elpek KG, Vinjamoori A, Zimmerman SM, Chu GC, Yan H, Fletcher-Sananikone E, Zhang H, Liu Y, Wang W, Ren X, Zheng H, Kimmelman AC, et al. PTEN is a major tumor suppressor in pancreatic ductal adenocarcinoma and regulates an NF-kappaB-cytokine network. Cancer discovery. 2011; 1:158-169.

19. Zimmer SN, Zhou Q, Zhou T, Cheng Z, AbboudWerner SL, Horn D, Lecocke M, White R, Krivtsov AV, Armstrong SA, Kung AL, Livingston DM, Rebel VI. Crebbp haploinsufficiency in mice alters the bone marrow microenvironment, leading to loss of stem cells and excessive myelopoiesis. Blood. 2011; 118:69-79.

20. Tetzlaff MT, Yu W, Li M, Zhang P, Finegold M, Mahon K, Harper JW, Schwartz RJ, Elledge SJ. Defective cardiovascular development and elevated cyclin E, Notch proteins in mice lacking the Fbw7 F-box protein. Proceedings of the National Academy of Sciences of the United States of America. 2004; 101:3338-3345.

21. Tsunematsu R, Nakayama K, Oike Y, Nishiyama M, Ishida N, Hatakeyama S, Bessho Y, Kageyama R, Suda T, Nakayama KI. Mouse Fbw7/Sel-10/Cdc4 is required for notch degradation during vascular development. The Journal of biological chemistry. 2004; 279:9417-9423.

22. Sancho R, Jandke A, Davis H, Diefenbacher ME, Tomlinson I, Behrens A. F-box and WD repeat domain-containing 7 regulates intestinal cell lineage commitment and is a haploinsufficient tumor suppressor. Gastroenterology. 2010; 139:929-941.

23. Yamamoto M, Furihata C, Ogiu T, Tsukamoto T, Inada K, Hirano K, Tatematsu M. Independent variation in susceptibilities of six different mouse strains to induction of pepsinogen-altered pyloric glands and gastric tumor intestinalization by N-methyl-N-nitrosourea. Cancer letters. 2002; 179:121-132.

24. Li Q, Jia Z, Wang L, Kong X, Li Q, Guo K, Tan D, Le X, Wei D, Huang S, Mishra L, Xie K. Disruption of Klf4 in villin-positive gastric progenitor cells promotes formation and progression of tumors of the antrum in mice. Gastroenterology. 2012; 142:531-542.

25. Jiang Y, Yu Y. Transgenic and gene knockout mice in gastric cancer research. Oncotarget. 2017; 8:3696-3710. doi: 10.18632/oncotarget.12467.

26. Hagedorn M, Delugin M, Abraldes I, Allain N, BelaudRotureau MA, Turmo M, Prigent C, Loiseau H, Bikfalvi A, Javerzat S. FBXW7/hCDC4 controls glioma cell proliferation in vitro and is a prognostic marker for survival in glioblastoma patients. Cell division. 2007; 2:9.
27. Snijders AM, Liu Y, Su L, Huang Y, Mao JH. Expression profiling reveals transcriptional regulation by Fbxw7/ mTOR pathway in radiation-induced mouse thymic lymphomas. Oncotarget. 2015; 6:44794-44805. doi: 10.18632/oncotarget.6328.

28. Lee JW, Soung YH, Kim HJ, Park WS, Nam SW, Kim SH, Lee JY, Yoo NJ, Lee SH. Mutational analysis of the hCDC4 gene in gastric carcinomas. European journal of cancer. 2006; 42:2369-2373.

29. Hu N, Kadota M, Liu H, Abnet CC, Su H, Wu H, Freedman ND, Yang HH, Wang C, Yan C, Wang L, Gere S, Hutchinson A, et al. Genomic landscape of somatic alterations in esophageal squamous cell carcinoma and gastric cancer. Cancer research. 2016; 76:1714-23.

30. Wang K, Yuen ST, Xu J, Lee SP, Yan HH, Shi ST, Siu HC, Deng S, Chu KM, Law S, Chan KH, Chan AS, Tsui WY, et al. Whole-genome sequencing and comprehensive molecular profiling identify new driver mutations in gastric cancer. Nature genetics. 2014; 46:573-582.

31. Mao JH, Kim IJ, Wu D, Climent J, Kang HC, DelRosario R, Balmain A. FBXW7 targets mTOR for degradation and cooperates with PTEN in tumor suppression. Science. 2008; 321:1499-1502.

32. Matsuoka S, Oike Y, Onoyama I, Iwama A, Arai F, Takubo K, Mashimo Y, Oguro H, Nitta E, Ito K, Miyamoto K, Yoshiwara H, Hosokawa K, et al. Fbxw7 acts as a critical fail-safe against premature loss of hematopoietic stem cells and development of T-ALL. Genes \& development. 2008; 22:986-991.

33. Yokobori T, Mimori K, Iwatsuki M, Ishii H, Onoyama I, Fukagawa T, Kuwano H, Nakayama KI, Mori M. p53Altered FBXW7 expression determines poor prognosis in gastric cancer cases. Cancer research. 2009; 69:3788-3794.

34. Dai W, Wang Q, Liu T, Swamy M, Fang Y, Xie S, Mahmood R, Yang YM, Xu M, Rao CV. Slippage of mitotic arrest and enhanced tumor development in mice with BubR1 haploinsufficiency. Cancer research. 2004; 64:440-445.

35. Yu S, Yang M, Nam KT. Mouse models of gastric carcinogenesis. Journal of gastric cancer. 2014; 14:67-86.

36. Beranek DT. Distribution of methyl and ethyl adducts following alkylation with monofunctional alkylating agents. Mutation research. 1990; 231:11-30.

37. Tu WZ, Li B, Huang B, Wang Y, Liu XD, Guan H, Zhang SM, Tang Y, Rang WQ, Zhou PK. gammaH2AX foci formation in the absence of DNA damage: mitotic H2AX phosphorylation is mediated by the DNA-PKcs/CHK2 pathway. FEBS letters. 2013; 587:3437-3443.

38. Valdiglesias V, Giunta S, Fenech M, Neri M, Bonassi S. gammaH2AX as a marker of DNA double strand breaks and genomic instability in human population studies. Mutation research. 2013; 753:24-40.

39. Fatur T, Lah T, Filipic M. Cadmium inhibits repair of UV-, methyl methanesulfonate- and N-methyl-N-nitrosourea- 
induced DNA damage in Chinese hamster ovary cells. Mutat Res. 2003; 529:109-116.

40. Singh NP, McCoy MT, Tice RR, Schneider EL. A simple technique for quantitation of low levels of DNA damage in individual cells. Experimental cell research. 1988; 175: 184-191.

41. Collins AR, Dobson VL, Dusinska M, Kennedy G, Stetina R. The comet assay: what can it really tell us? Mutation research. 1997; 375:183-193.

42. Celeste A, Difilippantonio S, Difilippantonio MJ, Fernandez-Capetillo O, Pilch DR, Sedelnikova OA, Eckhaus M, Ried T, Bonner WM, Nussenzweig A. H2AX haploinsufficiency modifies genomic stability and tumor susceptibility. Cell. 2003; 114:371-383.
43. Gorrini C, Squatrito M, Luise C, Syed N, Perna D, Wark L, Martinato F, Sardella D, Verrecchia A, Bennett S, Confalonieri S, Cesaroni M, Marchesi F, et al. Tip60 is a haplo-insufficient tumour suppressor required for an oncogene-induced DNA damage response. Nature. 2007; 448:1063-1067.

44. Rao CV, Yang YM, Swamy MV, Liu TY, Fang YQ, Mahmood R, Jhanwar-Uniyal M, Dai W. Colonic tumorigenesis in BubR1(+/-) Apc(Min/+) compound mutant mice is linked to premature separation of sister chromatids and enhanced genomic instability. Proceedings of the National Academy of Sciences of the United States of America. 2005; 102:4365-4370. 